\title{
繊維補強コンクリートの材料特性を考慮した CES 柱の終局耐力に関する考察 INVESTIGATION OF ULTIMATE STRENGTH OF CES COLUMNS CONSIDERING MATERIAL PROPERTIES
}

\author{
藤本利 昭*, 倉本 洋**, 松井智哉***, 小松 博**** \\ Toshiaki FUJIMOTO, Hiroshi KURAMOTO, Tomoya MATSUI \\ and Hiroshi KOMATSU
}

\begin{abstract}
Concrete Encased Steel (CES) structural system consisting of fiber reinforced concrete (FRC) and encased steels is a new composite structural system proposed by the authors, and is being conducted continuous and comprehensive studies to make it practical. This paper discusses how to evaluate the ultimate strength of CES columns. It is revealed based on the test results that the AIJ design formulas for SRC structures can be applied for evaluating the ultimate strengths of CES columns. Furthermore, improved design formulas to estimate the ultimate strength are proposed for CES columns considering material properties.
\end{abstract}

Keywords : CES column, Fiber reinforced concrete, Structural performance, Ultimate strength, Superposing strength method

$\mathrm{CES}$ 柱，繊維補強コンクリート，構造性能，終局耐力，累加強度

\section{1. はじめに}

繊維補強コンクリート（Fiber Reinforced Concrete，以下 FRC と略 記）は，コンクリートの脆性的な破壊特性を改善する目的で, 既に 幾つかの研究が行われている。それらのうち，材料特性に関する研 究によれば, 圧縮, 引張および曲げ強度に関しては, 䋊維混入前の コンクリートと大きく変わらないものの, 最大強度に達した後の強 度劣化特性（勒性）が改善されることが報告されている ${ }^{1)} 。$

一方，被覆コンクリートに FRC を用いた鉄骨コンクリート柱 （Concrete Encased Steel Column, 以下 CES 柱と略記）に関する既往 の研究では, 終局曲げ耐力は日本建築学会「鉄骨鉄筋コンクリート 構造計算規準・同解説」 ${ }^{2}$ (以下, SRC 規準と略記) の一般化累加 耐力でほぼ評価できることが報告されている33), 4)

$\mathrm{SRC}$ 規準による一般化累加耐力式 (以下, SRC 規準式と略記) は, 鉄骨については全塑性状態を仮定し，コンクリートについては，引 張強度を無視し圧縮強度のみを考慮した長方形のストレスブロック が用いられる。そのコンクリートのストレスブロックは, 応力分布 （ひずみ分布）と鉄骨による断面欠損の影響をコンクリート強度の低 減係数 ${ }_{c} r_{u}$ で考慮している。

SRC 規準式をCES 柱に適用するためには, SRC 柱のかぶりコン
クリート部と補強筋により横拘束されたコンクリート部に対して, 設定されたストレスブロックと繊維のみによって補強された CES 柱の FRC のストレスブロックが同等と評価できることを確認する 必要がある。また, 前述のとおり SRC 規準式では, 引張応力を受け るコンクリートは無視されており, 普通コンクリートに比べ勒性が 向上寸るという FRC の引張特性が考慮されないことになる。

そこで本研究では, まずFRCの材料試験結果を基に応力ーひずみ 関係を定式化し，そのモデルを基に実験結果との比較により CES 柱 の圧縮性状ならびに曲げ性状について考察する。更にそれらの検討 結果を基に CES 柱の終局耐力評価方法として, SRC 規準式の適用の 妥当性を検証すると共に, 更に精度良く終局耐力を評価できる FRC のストレスブロックの提案を試みる。

\section{FRC の応カーひずみ関係のモデル化}

既往の材料試験結果を基に，FRC の応力ーひずみ関係の定式化を 試みる。なおここでは，CES 柱の実験で主に用いられている繊維径 $0.66 \mathrm{~mm}$, 繊維長 $30 \mathrm{~mm}$ のビニロンファイバー（RF4000）を体積混 入率 $\left(V_{f}\right)$ で $1.0 \sim 2.0 \%$ 混入した FRC を対象とした ${ }^{3), 4)}$ 。

\footnotetext{
* 安藤建設侏技術研究所 主管研究員・博士 (工学)

* 大阪大学大学院工学研究科地球総合工学専攻 教授・博士 (工学)

*** 豊橋技術科学大学大学院工学研究科 建築・都市システム学系 助教・博士 (工学)

Senior Research Eng., Ando Corp. Research Center, Dr. Eng. Prof., Dept. of Architectural Engineering, Osaka University, Dr. Eng.

Assistant Prof., Dept. of Architecture \& Civil Eng., Toyohashi University of Technology, Dr. Eng.

Prof., Dept. of Architecture and Architectural Eng., College of Industrial Tech., Nihon University, Dr. Eng.
} 


\section{1 引張カを受ける FRC の応カーひずみ関係}

図 1 は, 文献 3)のビニロンファイバーを用いた $V_{f}=1.0 \%$ で圧縮強 度 $\sigma_{B}=52.3 \mathrm{~N} / \mathrm{mm}^{2}$ の FRC, $V_{f}=2.0 \%$ で $\sigma_{B}=55.5 \mathrm{~N} / \mathrm{mm}^{2}$ の FRC の直接 引張試験から得られた応力ーひずみ関係である。

普通コンクリートが引張力を受けると, ひび割れが発生し急激に 耐荷力を袁失する。一方引張力を受ける FRC は, 図 1 に示すように コンクリートの引張強度に達すると, ひび割れが発生し強度が一旦 低下寸るものの, その後繊維補強効果によりある一定の応力度を保 持寸る ${ }^{1), 3)}$ 。但し, FRC の引張強度は繊維混入前のベースコンクリ ート（普通コンクリート）と同等である ${ }^{1)}$ 。

\section{2 曲げモーメントを受ける FRC の応カーひずみ関係}

図 2 は, 図 1 と同じ FRC の曲げ試験から得られた応力一変位関係 である。なお図の縦軸は曲げモーメントを断面係数 $Z$ で除して求め た応力であり，横軸は試験体の鉛直変位（たわみ量）である。

普通コンクリートの場合, 断面の引張縁が引張強度に達するとひ び割れが発生し，急激に耐荷力を喪失する。一方既往の FRC の曲げ 試験結果 ${ }^{1)}$ ３)，5)によれば，FRCの曲げ強度は普通コンクリートと同 等であるものの，図 2 に示寸ようにひび割れ発生後の勒性が著しく 向上する。そこでこのような FRCの曲げ挙動を確認するため, FRC の曲げ試験供試体を対象に, ファイバーモデルによる曲げ解析によ り検討した。解析は, 図 3 に示寸ように試験体断面 $(b \times D=100 \times 100)$ の高さ方向を 16 分割して行った。

図 4 に解析に用いた応力ーひずみ関係を示す。解析に用いた FRC の引張応力ーひずみ関係は, 2.1 節の引張試験結果を参考に引張強 度 $\sigma_{t}$ 到達後一旦低下し, その後一定の応力度を保つモデルを仮定 した。ここで, 曲げモーメントを受ける普通コンクリート引張縁の 引張強度は, 直接引張試験から得られる引張強度に比べ 2 倍程度の 值になること ${ }^{1)}$ ，また曲げモーメントを受ける FRC の引張強度は， 普通コンクリートと同等であることから, 日本建築学会「鉄筋コン クリート構造計算規準・同解説」 ${ }^{6}$ （以下, RC 規準と略記）のコン クリートの引張強度を用いた。

$$
\sigma_{t}=0.56 \sqrt{\sigma_{B}}
$$

ここで, $\sigma_{B}$ : コンクリートの圧縮強度である。

解析は, FRC が引張応力度に達した後に保持寸る応力度の比 $\alpha$ をパラメータとした。 $\alpha=0$ は繊維を混入する前のベースコンクリー トの応力ーひずみ関係結果を表し， $\alpha=1.0$ はバイリニア型の応力ー ひずみ関係を表す。図 1 の引張試験による FRC の応力ーひずみ関係
は $\alpha=0.2$ に相当する。

図 5 にファイバーモデルによる解析結果を示す。なお図の縦軸は 図 2 と同様に曲げモーメントを断面係数 Zで除して求めた応力であ り，横軸は曲率 $\phi$ とした。解析結果によれば， $\alpha=1.0$ のバイリニア 型の応力ーひずみ関係では曲げ強度が高く評価されてしまう。図 2 に示したような FRC の曲げ挙動を示すのは $\alpha=0.4 \sim 0.6$ 程度の場合 であり, 引張試験による応力ーひずみ関係を表す $\alpha=0.2$ に比べ大き い。この違いは引張試験と曲げ試験による引張強度の違いと同様に 断面が均一なひずみを受ける引張試験と断面にひずみ勾配がある曲 げ試験との違いと考えられる。なお図 1 および図 2 の結果では, 繊 維の体積混入率 $V_{f}$ によって若干挙動が異なっているように見受けら れるが，文献 1)および 5)の実験結果も併せて評価すると， $V_{f}=1.0$ $2.0 \%$ 程度の範囲では繊維混入量の違いは明らかではないことから, 本研究で対象としている曲げ引張力を受ける FRC は, 引張強度に達 した後もその $1 / 2(\alpha=0.5)$ 程度の強度を維持するものと考えた。
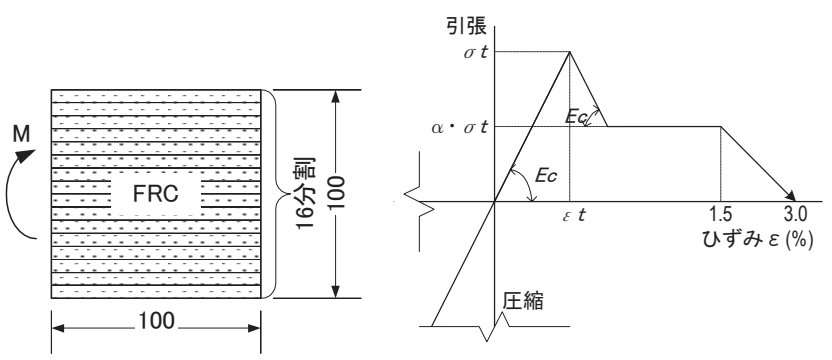

図 $3 \mathrm{FRC}$ の断面分割 図 4 FRC の引張応力ーひずみ関係の仮定

\section{3 圧縮カを受ける FRC の応カーひずみ関係}

FRC シリンダーの圧縮試験によれば，圧縮力を受ける FRC の応 カーひずみ関係は, 繊維混入前のベースコンクリートに比べ強度の 上昇はないものの, 圧縮強度到達後の応力劣化勾配が緩やかになる。 このような挙動は, 角形鋼管を用いた CFT 柱の充填コンクリートの 挙動と類似している7)。そこで, 圧縮力を受ける FRC の応力ひずみ 関係は，圧縮強度以降では文献 7)に示された崎野らのモデルを基に 下式により表すこととした。

$$
\begin{aligned}
& Y=\frac{V X+(W-1) X^{2}}{1+(V-2) X+W X^{2}} \\
& X=\varepsilon_{c} / \varepsilon_{c o}, \quad Y=\sigma_{c} / \sigma_{B}, \quad V=E_{c} \cdot \varepsilon_{c o} / \sigma_{B}, \\
& W=1.5-17.1 \sigma_{B} \times 10^{-3}+2.39 \sqrt{\sigma_{r e}}, \quad E_{c}=\left(6.90+3.32 \sqrt{\sigma_{B}}\right) \times 10^{3}, \\
& \varepsilon_{c o}=0.94\left(\sigma_{B}\right)^{1 / 4} \times 10^{-3}
\end{aligned}
$$

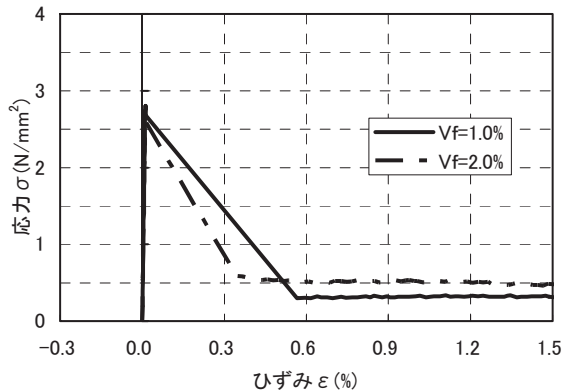

図 1 FRC の引張試験による応力ーひずみ関係 ${ }^{3)}$

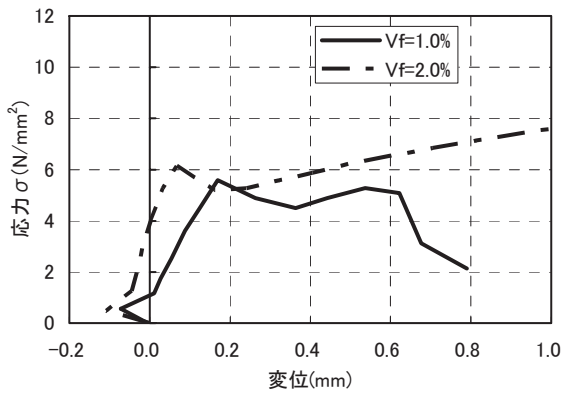

図 2 FRC の曲げ試験による応力一変位関係 ${ }^{3)}$

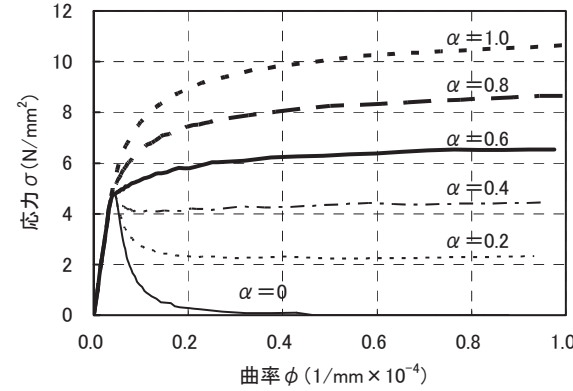

図 5 曲げ解析による応力一曲率関係 
ここで， $\varepsilon_{c}$ : コンクリートの圧縮ひずみ, $\varepsilon_{c o}$ : コンクリートの 圧縮強度時ひずみ, $\sigma_{c}$ : コンクリートの圧縮応力, $E_{c}$ : ヤング率, $\sigma_{r e}$ : 有効側圧因子である。

式(2)において, 圧縮強度到達後の劣化勾配は, $W$ りりは有効側 圧因子 $\sigma_{r e}$ によって決定される。そこで FRC の圧縮試験結果と一致 するような $\sigma_{r e}$ の值を計算した結果, 図 6 に示すとおり䋊維混入量 が 1 ～ $2 \%$ 程度においては $\sigma_{r e}=0.016$ とすることで，ほぼ表せるこ とがわかった。

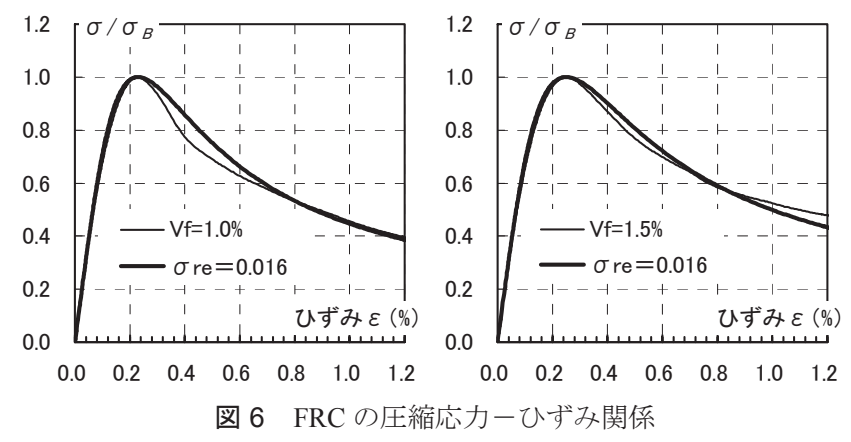

3. 荷重一変形関係に対するモデルの検証

3.1 CES 柱の軸圧縮性状

2.3 節で提案した圧縮力を受ける FRC の応力ーひずみ関係モデル の妥当性を確認するため, 文献 8)の CES 柱の中心圧縮実験結果を対 象にモデルとの比較を行った。検討対象とした試験体は，断面形状 を $b \times D=150 \times 150 \mathrm{~mm}$ の正方形断面とし，SS400 材を用いた $\mathrm{H}$ 形鋼 $(\mathrm{H}-100 \times 100 \times 6 \times 8)$ ，交差型 $\mathrm{H}$ 形鋼 $(2-\mathrm{H}-100 \times 50 \times 5 \times 7)$ を緎維 補強コンクリート $\left(\sigma_{B}=34.1 \mathrm{~N} / \mathrm{mm}^{2}\right.$, 体積混入率 $\left.\mathrm{V}_{\mathrm{f}}=1.0 \%\right)$ で被覆し た 2 体である。

FRC の圧縮応力ーひずみ関係は, 式(2)を用い, 有効側圧因子 $\sigma_{r e}=0.016$ とした。なお式(2)による FRC の応力ーひずみ関係は，ひ ずみの測定長を断面せい $D$ とした材料試験結果に基づいており，局 所化した破壊領域の応力ーひずみ関係を表していると言える。一方 中心圧縮実験では，ひずみの測定長を断面せい $D$ の 3 倍としている ことから, 破壊領域以外も含んだひずみを表していると考えられる。 そこで中心圧縮実験におけるコンクリートの応力ーひずみ関係の負 勾配部分の傾きは，材料試験結果に対して 3 倍して用いることとし た 9)。また, 内蔵鉄骨の応力ーひずみ関係はバイリニアに仮定した。

図 7 に実験結果とモデルとの比較を示す。交差型 H 形鋼を内蔵し た試験体では，軸ひずみが $1 \%$ 超えるあたりから実験と解析とに 差が生じているが, 実験結果の最大耐力点および最大耐力直後の劣 化勾配は良好に表現できている。よって CES 柱に用いる FRC の圧

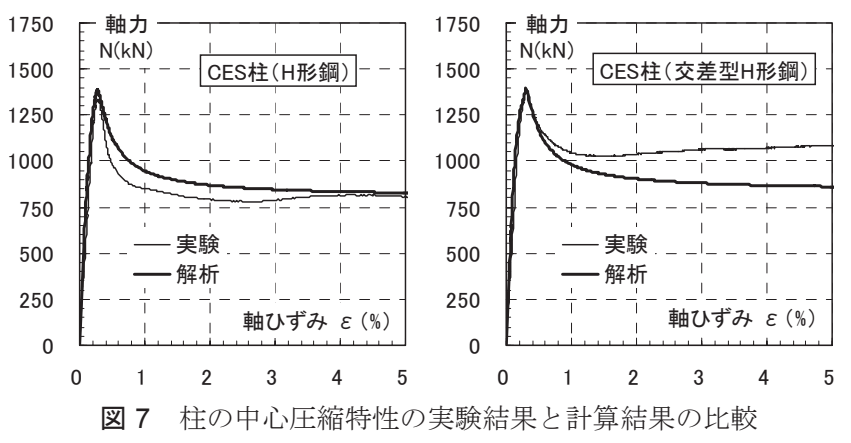

縮特性は, 2.3 節に示したモデルによって概ね表現できるものと考 えられる。

\subsection{CES 柱の曲げ性状}

図 8 に H 形鋼ならびに交差型 $\mathrm{H}$ 形鋼を内蔵した CES 柱 ${ }^{3), 4), 10), 11) ~}$ のせん断力ー部材角 $(Q-R)$ 関係の骨格曲線をファイバーモデルに よる解析と比較した結果を示す。解析に用いた FRCの引張応力ーひ ずみ関係は，FRCのひび割れ強度後の勒性を考慮したモデル（図 4 の $\alpha=0.5)$ とした。但し引張試験結果を参考に，ひずみ $1.5 \%$ 以降は 強度が低下し $3 \%$ で応力が 0 となるようなモデルにしている。また， FRC の圧縮応力ーひずみ関係は，2.3 節を基に式(2)を用い有効側圧 因子 $\sigma_{r e}=0.016$ とした。なお内蔵鉄骨の応力ーひずみ関係はバイリ ニアに仮定した。また解析結果の縦軸のせん断力は，柱材端を危険 断面として算出した值であり，横軸の部材角 $R$ は材軸方向の曲率 $\phi$ の分布が，曲げモーメント分布に比例すると仮定した場合の関係式 $\phi=6 \cdot R / h$ （ $h$ : 柱内法高さ）を基に，実験值との適合性を試行錯誤的 に検討した結果, 最終的に $\phi=3 \cdot R / h$ と仮定した。

引張力を受ける FRC の応力ーひずみ関係の違いが CES 柱のせん 断力一部材角関係に与える影響を確認するため, 図 8(a)の試験体 B1 については, FRC の引張応力ーひずみ関係に FRC のひび割れ強度 後の勒性を無視したモデル（図 4 の $\alpha=0$ ）を用いた結果も併せて示 している。

図 8(a)より, 引張側 FRC のモデルの違いにより剛性, 耐力が異な り，引張強度と勒性を考慮することで，実験結果との対応が良くな っていることがわかる。既往の CES 柱を対象としたファイバーモデ ルによる解析 ${ }^{3}$ においても, 解析と実験の最大耐力の対応が良いこ とが報告されているが，それらの研究では内蔵鉄骨に囲まれた部分 の FRC の拘束効果を考慮して, 圧縮強度と勒性を高めている点が本 解析とは異なっている。

解析では鉄骨の局部座屈を考慮していないため, 実験で最大耐力 以降に内蔵 $\mathrm{H}$ 形鋼の局部座屈が生じた試験体 B3, B3L, B3H(図 8(c), (d), (e)) では, 最大耐力以降で実験と解析に差異が生じているが, 他の試験体に関しては, 内蔵鉄骨の形状，軸力比に関わらず FRCの 引張挙動を考慮したファイバーモデルによって, CES 柱の曲げ挙動 を良好に追跡できている。

\section{CES 柱の軸圧縮耐力}

文献 8)で報告された中心圧縮実験結果を基に, 以下に示す単純累 加耐力 $N_{0}$ および $\mathrm{SRC}$ 規準の圧縮耐力 $N_{u}$ と比較を行った。

$$
N_{0}=N_{s}+N_{c}=\sigma_{y} \cdot A_{s}+\sigma_{B} \cdot A_{c}
$$

ここで, $N_{s}, N_{c}$ : 鉄骨およびコンクリート部分の終局圧縮耐力, $\sigma_{y}$ : 鉄骨の降伏強度, $A_{s}, A_{c}$ : 鉄骨およびコンクリート部分の断面 積である。

$$
N_{u}=N_{s}+N_{c}=\sigma_{y} \cdot A_{s}+{ }_{c} r_{u} \cdot \sigma_{B} \cdot b \cdot D
$$

ここで, ${ }_{c} r_{u}$ : コンクリート強度の低減係数 $\left(=0.85-2.5{ }_{s} p_{c}\right),{ }_{s} p_{c}$ : 圧 縮側鉄骨比 $\left(={ }_{s} a_{c} / b D\right),{ }_{s} a_{c}$ : 圧縮側鉄骨フランジの断面積(但しここで は鉄骨の全断面積 ${ }_{s} a_{c}={ }_{s} A$ として評価した)である。 
表 1 に実験結果と計算結果を比較して示す。各試験体の最大耐力 $\left(N_{\text {exp }}\right)$ は, 式(3)による単純累加耐力 $N_{0}$ とほぼ一致しており, 内蔵鉄 骨の形状に関わらず, CES 柱の軸圧縮耐力は単純累加式により評価 できるといえる。また実験結果は SRC 規準の圧縮耐力 $N_{u}$ の 1.08 1.1 倍で，軸圧縮耐力が低く評価されることがわかった。

上記のことからも，繊維や内蔵鉄骨の拘束によるコンクリートの 強度上昇は無いものと考えられる。

表 1 CES 柱試験体の軸圧縮耐力一覧(単位 : $\mathrm{kN}$ )

\begin{tabular}{l||c|c|c|c|c|c|c}
\hline & $N_{c}$ & $N_{s}$ & $N_{0}$ & $N_{u}$ & $N_{\text {exp }}$ & $N_{\text {exp }} / N_{0}$ & $N_{\text {exp }} / N_{u}$ \\
\hline \hline CES 柱(H 形鋼) & 699 & 655 & 1354 & 1239 & 1336 & 0.99 & 1.08 \\
\hline CES 柱(交差型 H 形鋼 $)$ & 693 & 680 & 1373 & 1258 & 1388 & 1.01 & 1.10 \\
\hline
\end{tabular}

\section{CES 柱の曲げ耐力}

\section{1 ファイバーモデルによる検討}

3.2 節に示した FRC の応力ーひずみ関係を用いたファイバーモデ ルにより, CES 柱の終局曲げ耐力一軸力相関曲線 $(\mathrm{M}-\mathrm{N}$ 相関曲線） を検討した。3.2 節の解析における各試験体の最大耐力時の圧縮縁 ひずみ $\varepsilon_{c u}$ を表 2 に示す。 $\varepsilon_{c u}$ は $-0.349 \sim-0.426 \times 10^{-2}$ であり,こ の值は鉄筋コンクリート部材の終局耐力計算に一般的に用いられて いる $\varepsilon_{c u}=-0.3 \times 10^{-2}$ に比べ大きな值であった。このことから，フ アイバーモデルによる $\mathrm{M}-\mathrm{N}$ 相関曲線は, FRC の圧縮縁ひずみが $\varepsilon_{c u}=-0.35 \times 10^{-2}$ に達したときの耐力として計算した。

図 9 にファイバーモデルによる $\mathrm{M}-\mathrm{N}$ 相関曲線に実験值をプロッ トして示す。なお，図中には SRC 規準式による $\mathrm{M}-\mathrm{N}$ 相関曲線も比 較のため示している。
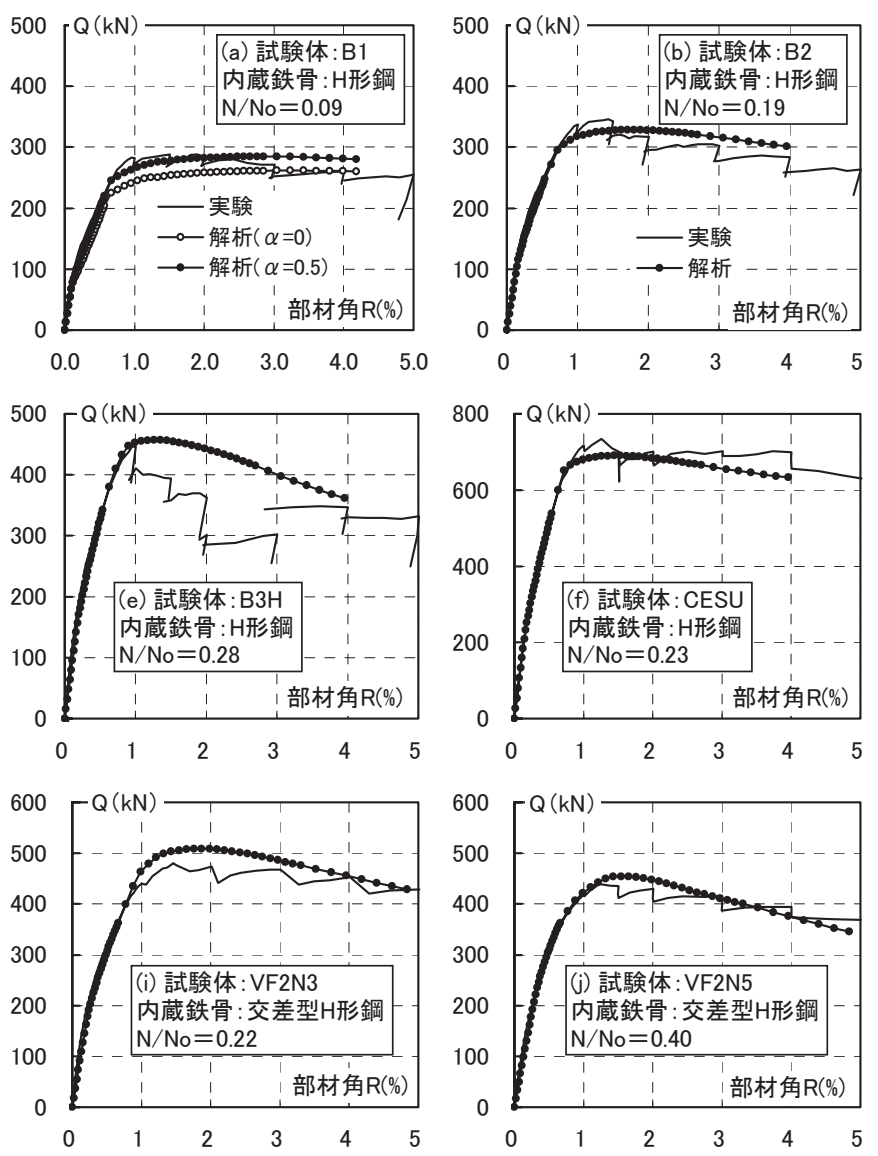

図 8 柱の $\mathrm{Q}-\mathrm{R}$ 関係の実験結果と計算結果の比較
$\mathrm{SRC}$ 規準式による CES 柱の $\mathrm{M}-\mathrm{N}$ 相関曲線は, 実験結果に対して 若干小さく安全側の評価となっている。一方ファイバーモデルによ る $\mathrm{M}-\mathrm{N}$ 相関曲線は, 交差型 $\mathrm{H}$ 形鋼の試験体の比較的高軸力の範囲 で $\mathrm{SRC}$ 規準の $\mathrm{M}-\mathrm{N}$ 相関曲線を下回る部分があるものの, SRC 規 準に比心゙概ね耐力が高く評価される傾向がある。また，ファイバー モデルによる $\mathrm{M}-\mathrm{N}$ 相関曲線は, SRC 規準式に比べ実験結果との対 応も良い。

表 2 曲げ耐力時の圧縮縁ひずみ

\begin{tabular}{c||c|c|c|c|c|c|c|c|c|c}
\hline 試験体 & B1 & B2 & B3 & B3L & B3H & CESU & VF1 & VF2 & VF2N3 & VF2N5 \\
\hline \hline $\begin{array}{c}\varepsilon_{c u} \\
\left({ }^{c} 0^{-2}\right)\end{array}$ & -0.398 & -0.351 & -0.349 & -0.358 & -0.356 & -0.369 & -0.398 & -0.410 & -0.426 & -0.403 \\
\hline
\end{tabular}

\section{2 一般化累加による CES 柱の曲げ耐力式の検討}

前節の検討で，ファイバーモデルによる解析から求めた $\mathrm{M}-\mathrm{N}$ 相 関曲線が，SRC 規準式に比べ実験結果との対応が良いことが明らか となった。しかしながらファイバーモデルによる耐力計算は，実務 では少々煩雑と考えられることから，一般化累加耐力式によって， より CES の耐力を精度よく算定することを目的として, FRC のスト レスブロックについて検討を行った。なお，柱の曲げ危険断面位置 は，材端にすることを前提に検討した。

（1） SRC 規準式のコンクリートのストレスブロックの検討

$\mathrm{SRC}$ 規準ではコンクリート部分の耐力計算に関して，ストレスブ ロックの低減係数として ${ }_{c} r_{u}$ が用いられる。 ${ }_{c} r_{u}$ は，コンクリート応 力分布と鉄骨によるコンクリート断面の欠損による影響を簡略化し て考慮した式となっている。前述のとおり， ${ }^{2} r_{u}$ は SRC 部材に対し
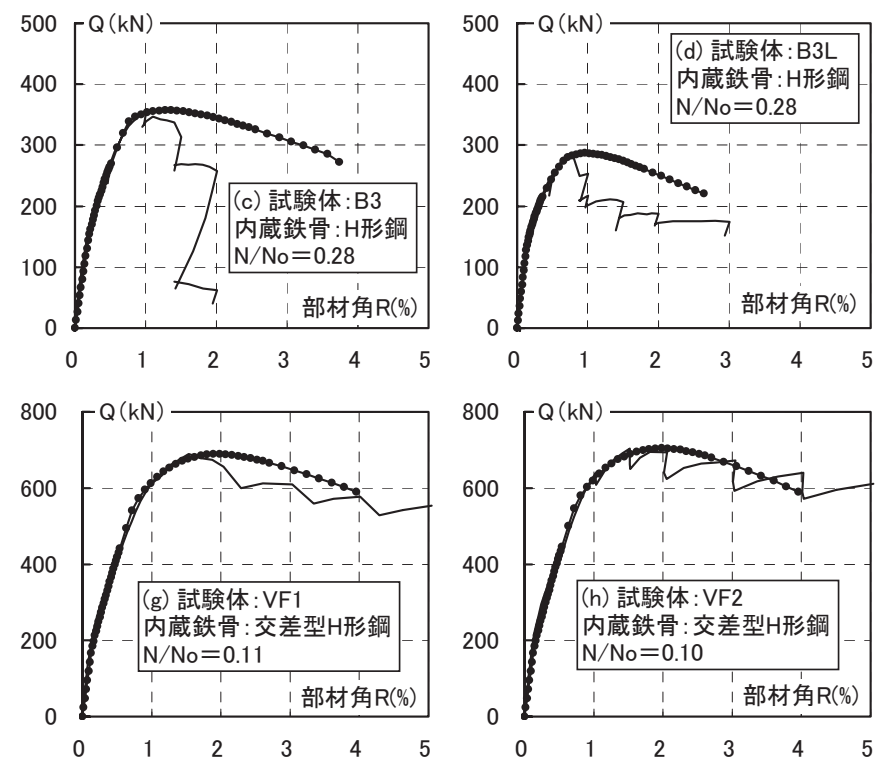

\begin{tabular}{|c|c|c|c|c|c|}
\hline 試験体 & $\begin{array}{l}\text { 繊維 } \\
V_{f}(\%) \\
\end{array}$ & $\begin{array}{l}b^{*} D \\
(\mathrm{~mm}) \\
\end{array}$ & & 鉄骨形状 & $N / N_{o}$ \\
\hline B1 & \multirow{5}{*}{1.0} & \multirow{5}{*}{$300 * 300$} & \multirow{6}{*}{$\begin{array}{l}\mathrm{H} \\
\text { 形 } \\
\text { 鋼 }\end{array}$} & \multirow{3}{*}{ H-200*150*6*9 } & 0.09 \\
\hline B2 & & & & & 0.19 \\
\hline B3 & & & & & 0.28 \\
\hline B3L & & & & $\mathrm{H}-150 * 150 * 6 * 6$ & 0.28 \\
\hline B3H & & & & H-200*150*9*16 & 0.28 \\
\hline CESU & 1.5 & \multirow{3}{*}{$400 * 400$} & & H-300*220*10*15 & 0.23 \\
\hline VF1 & 1.0 & & & 2 & 0.11 \\
\hline VF2 & \multirow{3}{*}{2.0} & & 父 & -30 & 0.10 \\
\hline VF2N3 & & \multirow{2}{*}{$330 * 330$} & \multirow{2}{*}{ 美 } & \multirow{2}{*}{$2 \mathrm{H}-250 * 125 * 6 * 9$} & 0.22 \\
\hline VF2N6 & & & & & 0.40 \\
\hline
\end{tabular}

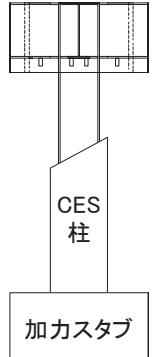


て設定された式であり, CES 柱ではコンクリートに FRC を用いて補 強筋を省略している点, SRC 柱に比べ鉄骨断面が大きい点が異なる ことからこれらの影響について検討を行った。

\section{a) 応カ分布に対するストレスブロックの低減係数の検討}

まず FRC の応力分布によるコンクリート強度の低減係数を調べ るため, 図 10 に示すように, 圧縮力を受ける FRC 応力ーひずみ関 係から求まる応力分布を, 長方形分布に置き換えた場合の低減係数 ${ }_{c} r_{u l}$ を検討した。検討方法は, まず 2.3 節で仮定した圧縮力を受ける FRC の応力ーひずみ関係を用いて, 圧縮縁ひずみ $\varepsilon_{c u}=-0.35 \times 10^{-2}$ までの応力分布から得られる軸力と曲げモーメントを求め, 次に長 方形ブロックから得られる軸力と曲げモーメントが等しくなるよう な低減係数 ${ }_{c} r_{u l}$ を求めた。なお, 応力分布に関しては, 圧縮強度が 影響することが考えられることから, 圧縮強度 $\sigma_{B}$ を変数として検 討を行った。

検討結果の一覧を表 3 に示す。応力分布形状の影響による低減係 数は, コンクリート強度によって若干の差はあるものの 0.9 前後で あり, 曲げ耐力を安全側に評価する観点では SRC 規準の 0.85 を用 いても問題ないものと考えられる。

\section{b) 鉄骨によるストレスブロックの低減係数の検討}

鉄骨による断面欠損がストレスブロックの低減係数に与える影響 を確認するため, ストレスブロックの違いによる $\mathrm{M}-\mathrm{N}$ 相関曲線へ の影響を検討した。

一例として, H 形鋼を内蔵した CES 柱（試験体 B1）, 交差型 $\mathrm{H}$ 形
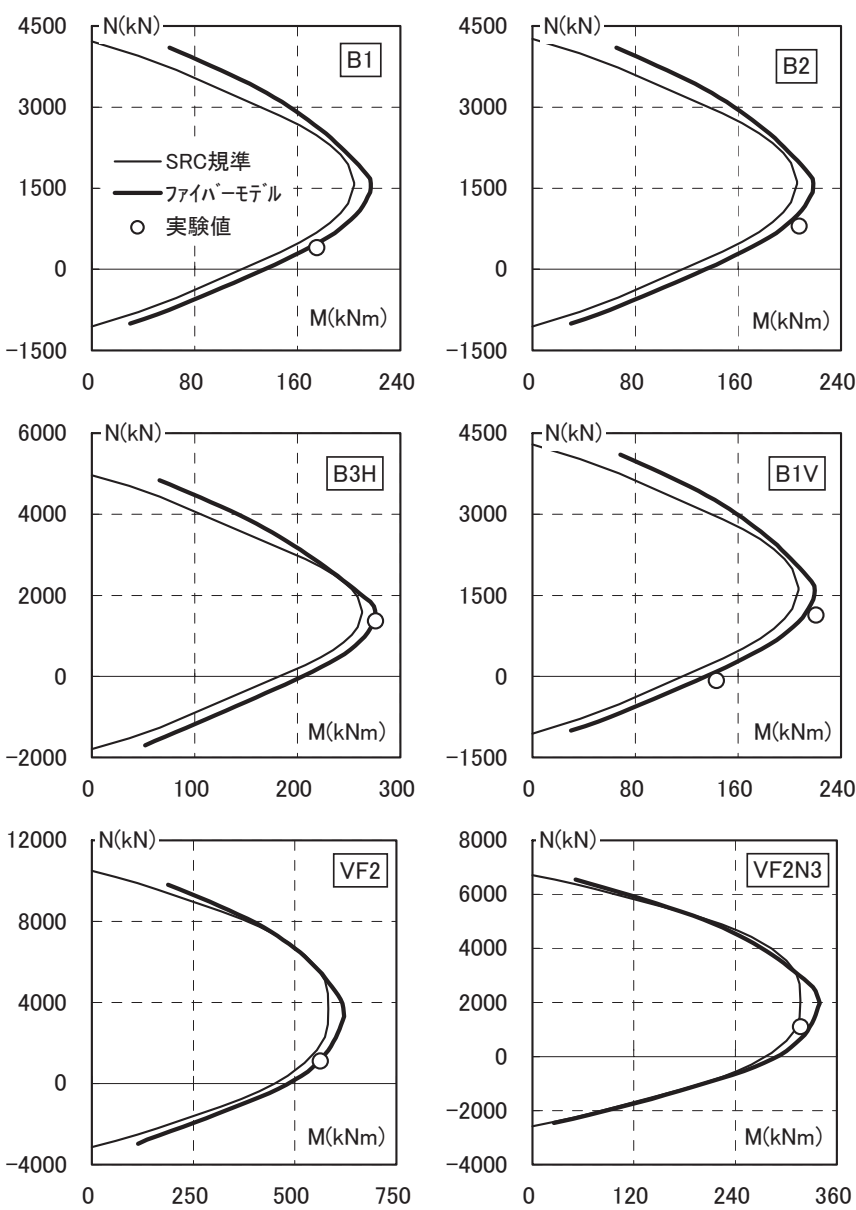

鋼を内蔵した CES 柱（試験体 VF1）について，ストレスブロックの 評価方法を変化させたコンクリート部分の $\mathrm{M}-\mathrm{N}$ 相関曲線を図 11a) に，柱の $\mathrm{M}-\mathrm{N}$ 相関曲線を図 $11 \mathrm{~b}$ )に示寸。図 11 には, SRC 規準式 のコンクリート強度の低減係数 ${ }_{c} r_{u}$ を用いた場合 (実線), コンクリ 一ト強度の低減係数 ${ }_{c} r_{u}$ を 0.85 とした場合 (図中 “ $\square ”$ ”), コンクリ 一下強度の低減係数 ${ }_{c} r_{u}$ を 0.85 とし, 更に鉄骨の断面欠損を考慮し た場合（図中“”）について示している。試験体 B1 では，コンク リート強度の低減係数 ${ }_{c} r_{u}$ を 0.85 とし, 更に鉄骨の断面欠損を考慮 した場合，SRC 規準式とほぼ一致している。一方試験体 VF1 では, コンクリート強度の低減係数 ${ }_{c} r_{u}$ を 0.85 とし, 更に鉄骨の断面欠損 を考慮した場合の耐力に比べ, SRC 規準の耐力は僅かであるが大き

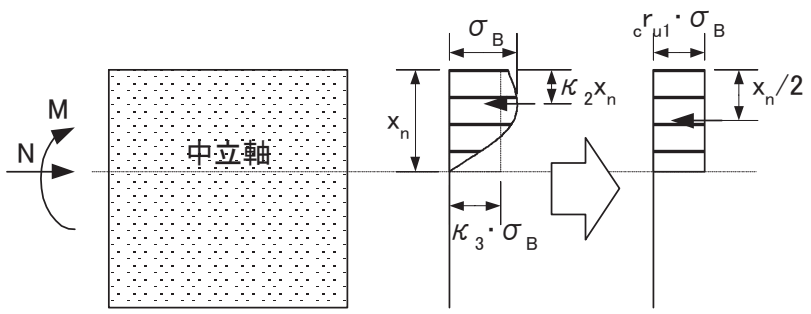

図 10 応力分布のストレスブロックへのモデル化

表 3 応力分布による低減係数 ${ }_{c} r_{u 1}$ 一覧

\begin{tabular}{c||c|c|c|c|c}
\hline \multicolumn{1}{c||}{} & \multicolumn{5}{c}{$\sigma_{B}\left(\mathrm{~N} / \mathrm{mm}^{2}\right)$} \\
\cline { 2 - 6 } & 20 & 30 & 40 & 50 & 60 \\
\hline \hline${ }_{c} r_{u 1}$ & 0.928 & 0.921 & 0.911 & 0.900 & 0.89 \\
\hline
\end{tabular}
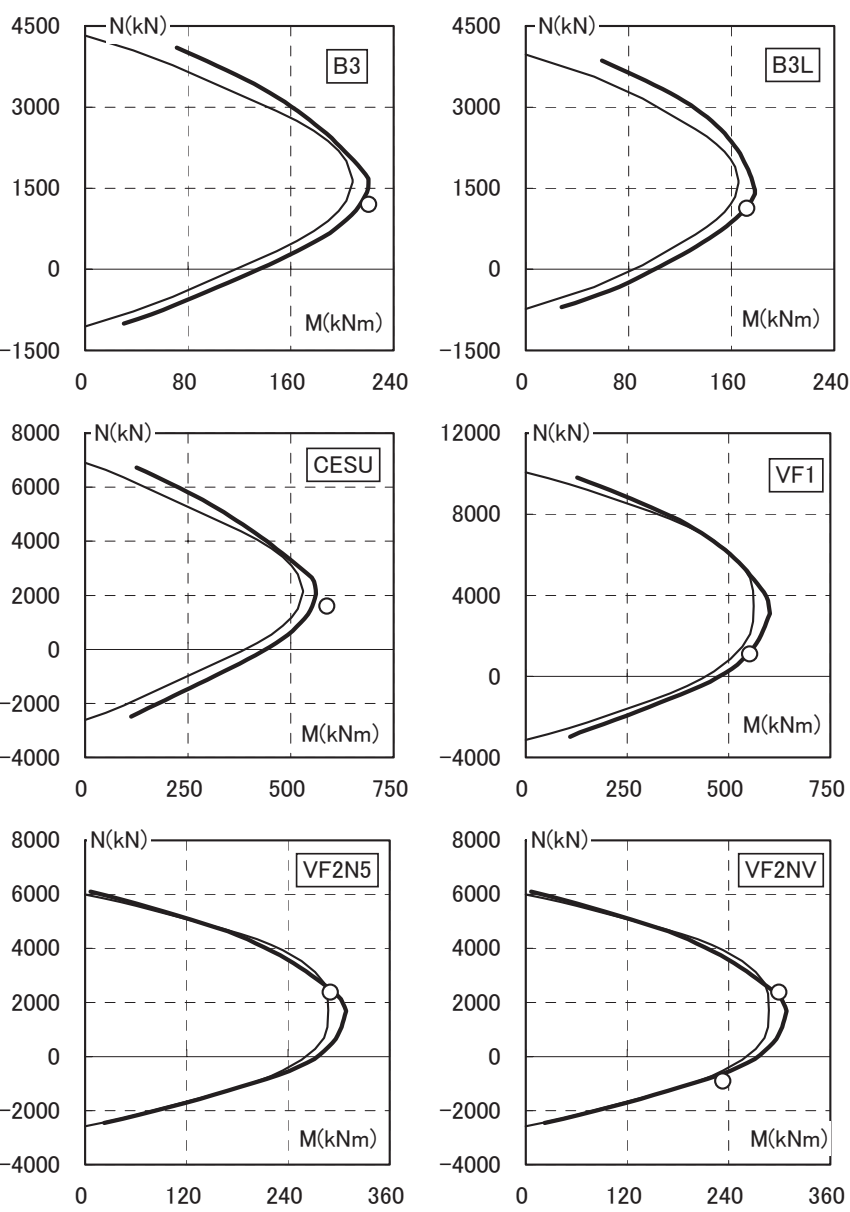

図 9 柱の曲げ耐力の実験值と $\mathrm{M}-\mathrm{N}$ 相関曲線の比較 
く評価されている。これは, 圧縮側鉄骨比 ${ }_{s} P_{c}$ が柱全断面に対する 1 つの鉄骨フランジの断面積の比で評価されることから, 内蔵鉄骨が $\mathrm{H}$ 形鋼の場合に対して, 交差型 $\mathrm{H}$ 形鋼を内蔵した場合, 1 つのフラ ンジの断面積が小さくなることが影響している。

これらの影響を図 11b)の CES 柱の耐力で見ると, 試験体 VF1の $\mathrm{SRC}$ 規準式とコンクリート強度の低減係数 ${ }_{c} r_{u}$ を 0.85 とし, 更に鉄 骨の断面欠損を考慮した場合の耐力の差は更に僅かとなる。ここで 応力分布によるコンクリート強度の低減係数を小さく評価している ことを含めて総合的に判断すれば, コンクリート強度の低減係数 ${ }_{c} r_{u}$ は SRC 規準式の值を用いて評価できるものと考えられる。

一方で, コンクリートの圧縮ストレスブロックを変化させた場合, コンクリートの曲げ耐力と圧縮側の軸耐力が変化するため, 比較的 軸力が低い CES 柱試験体の曲げ耐力の評価精度は改善されない。よ
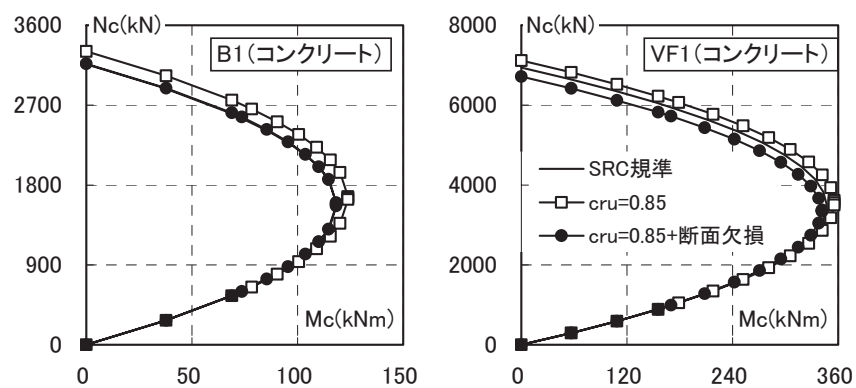

a) コンクリート部分

図 11 コンクリートのストレスブロックの違いに上ろ $\mathrm{M}-\mathrm{N}$ 相関曲線の比較
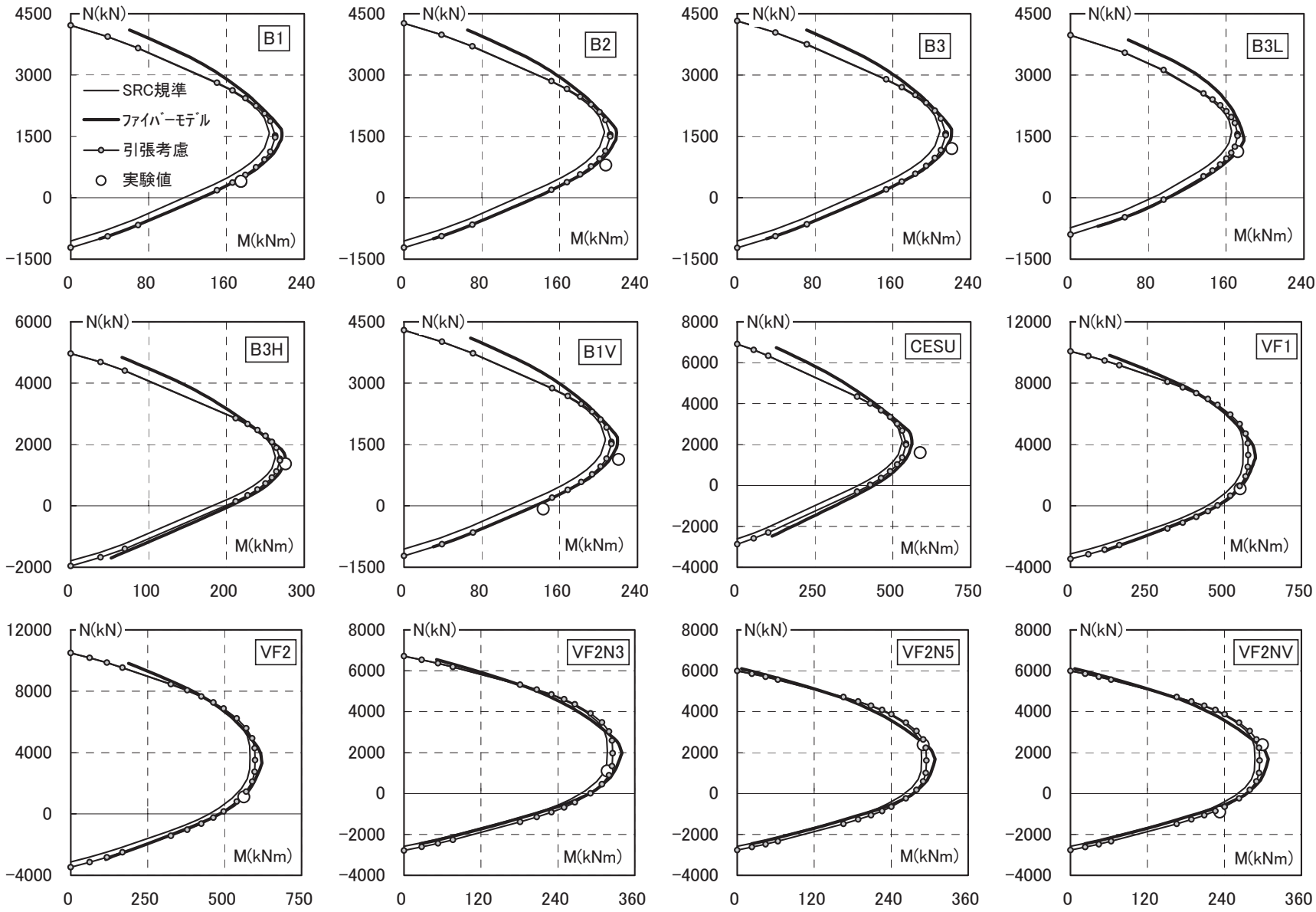

図 $13 \mathrm{FRC}$ の引張特性を考慮した耐力式による $\mathrm{M}-\mathrm{N}$ 相関曲線の比較

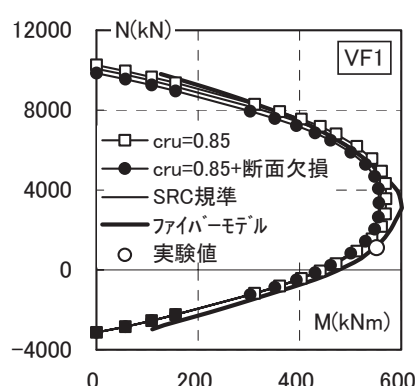

CES 柱

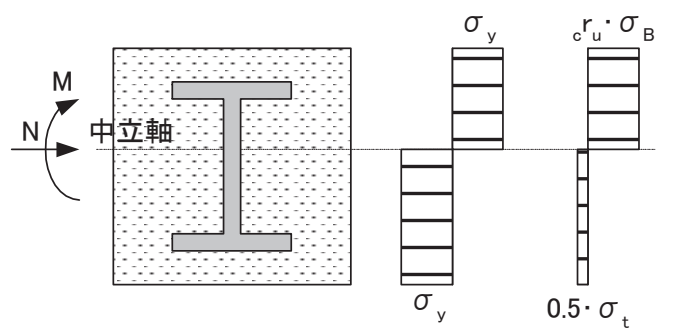

図 12 提案するストレスブロック

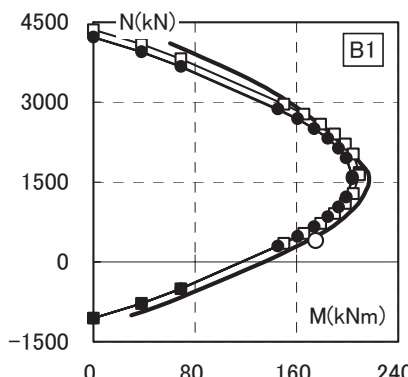

軸力の領域の $\mathrm{M}-\mathrm{N}$ 相関曲線を改善するためには, FRC の引 (2) FRCの引張特性を考慮した耐力式

上記の検討結果から，図 12 に示す FRC の引張強度を考慮した一 般化累加耐力式を提案する。

$$
\text { - }
$$


ここで，FRC のストレスブロックは，圧縮側は SRC 規準と同様 の值とし, 引張側のストレスブロックとして, 式(1)のコンクリート の引張強度 $\sigma_{t}$ の 0.5 倍とした。この值は, 2.2 節で示した FRC の曲 げ試験に対するファイバーモデルによる解析で用いた, 曲げ引張力 を受ける FRC の応力ーひずみ関係（図４参照）における強度低下後 に維持する応力度の比 $\alpha=0.5$ に相当する。

図 12 のストレスブロックを用いて計算した CES 柱の $\mathrm{M}-\mathrm{N}$ 相関 曲線を, 図 9 にプロットしたものを図 13 に示す。

図 12 のストレスブロックを用いた曲げ耐力は, SRC 規準式に比 べ引張軸力及び低軸力における曲げ耐力が高く評価され, ファイバ 一モデルおよび実験結果との対応が良くなっていることがわかる。 また, 圧縮軸力が高い範囲では, SRC 規準とほぼ同等になっている。 以上のことから, FRCの引張強度を考慮した本提案式で, CES 柱 の終局耐力をより精度良く評価できるものと考えられる。

\section{6. まとめ}

繊維補強コンクリートの材料特性に着目し, CES 柱の終局耐力に 関して考察した。

・ CES 柱に用いる FRC の圧縮, 引張, 曲げ性状を表す応力ーひず み関係を提案した。

・提案した FRCの応力ーひずみ関係により, CES 柱の軸圧縮性状 を精度良く評価できる。

・提案した FRC の応力ーひずみ関係を用いたファイバーモデルに より, CES 柱の曲げ性状, 終局曲げ耐力を精度良く評価できる。

- SRC 規準の一般化累加耐力式は, CES 柱の軸圧縮耐力および曲 げ耐力を安全側に評価する。

・ SRC 規準の一般化累加耐力式に, FRC の引張ストレスブロック を用いる終局耐力評価方法を提案し，CES 柱の終局曲げ耐力を 精度良く評価できることを示した。

なお，実際の CES 構造建物においては，CES 柱の材端部（柱頭お よび柱脚部）において, FRCの打ち継ぎ面や鉄骨梁等のディテール により FRC が分断される場合も予想される。そのような場合には, $\mathrm{FRC}$ の引張強度が期待できないため, SRC 規準式により設計すれば 良いものと考える。

\section{謝辞}

本研究は，日本建築学会 鋼コンクリート合成構造運営委員会に 設置された CES 構造性能評価小委員会 (主查: 倉本洋 大阪大学教 授)ならびに CES 構造解析 WG の活動の一環として実施したもので ある。小委員会ならびに WG 委員の皆様には貴重なご意見をいただ きました。ここに記して謝意を表します。

参考文献

1) 住学, 竹内博幸, 中出睦, 谷垣正治：ビニロン繊維補強コンクリートに 関する基礎的研究，コンクリート工学年次論文集，Vol.25, No.1，2003

2) 日本建築学会：鉄骨鉄筋コンクリート構造計算規準・同解説，2001.1

3) 足立智弘, 倉本洋, 川崎清彦: 繊維補強コンクリートを用いた鉄骨コン クリート合成構造柱の構造性能に関する実験的研究，コンクリート工学 年次論文集，第 24 巻，第 2 号，pp.271-276，2002.6.

4) 溝淵博己, 松井智哉, 藤本利昭, 倉本洋: 軸力比およびシアスパン比が 異なる $\mathrm{H}$ 型鉄骨内蔵 CES 柱の静的載荷実験, 第 8 回複合・合成構造の活 用に関するシンポジウム，CD-ROM，2009.11

5) 田口孝，神谷隆，倉本洋：材料特性の異なる FRC を用いた外付耐震補強 工法における CES 補強柱の構造性能, 第 8 回複合・合成構造の活用に関 するシンポジウム, CD-ROM， 2009.11

6) 日本建築学会 : 鉄筋コンクリート構造計算規準・同解説，1999

7) Kenji Sakino, Hiroyuki Nakahara, Shosuke Morino and Isao Nishiyama : Behavior of Centrally Loaded Concrete-Filled Steel-Tube Short Columns, Journal of Structural Engineering, ASCE, Volume 130, Number 2, pp.180-188, 2004.2.

8) 小松博, 藤本利昭, 櫻田智之：再生骨材コンクリートを用いた合成構造 柱の圧縮試験(その $1 \sim 2$ ), 日本建築学会大会学術講演梗概集, C-1, pp.1365-1366, 2010.9

9) 稲井栄一, 西山功, 崎野健治 : ハイブリッド構造に関する日米共同構造 実験研究 (CFT-19) コンクリート充てん鋼管柱の復元力特性のシミュレ 一ションーその 1 解析手法の概要一, 日本建築学会大会学術講演梗概集, C-1， pp.921-922， 1997.9

10) 足立智弘，倉本洋，川崎清彦，柴山豊：高軸力を受ける繊維補強コンク リートー鋼合成構造柱の構造性能に関寸る研究, コンクリート工学年次 論文集，第 25 巻，第 2 号，pp.289-294，2003.6.

11) 田口孝, 永田諭, 松井智哉, 倉本洋 : H 型鉄骨を内蔵した CES 柱の構造 特性, コンクリート工学年次論文集第 28 巻, 第 2 号, pp.1273-1278, 2006.7

(2010年 5 月 10 日原稿受理, 2010年 9 月 7 日採用決定） 